\title{
Kecenderungan Pembelian Impulsif Ditinjau dari Perspektif Islam (Studi Kasus Pada Pengunjung Malioboro Mall Yogyakarta)
}

\author{
Dimas Pratomo \\ UIN Raden Intan Lampung \\ dimaspratomo@radenintan.ac.id \\ Liya Ermawati \\ UIN Raden Intan Lampung \\ Liyaermawati@radenintan.ac.id
}

\begin{abstract}
Abstrak
Saat ini kebutuhan masyarakat semakin kompleks dan beragam. Sehingga seringkali masyarakat dalam berbelanja dilakukan secara spontan karena berbagai variasi produk yang ada. Penelitian ini bertujuan untuk melihat seberapa besar kecenderungan masyarakat provinsi DIY sebagai pengunjung Mall Malioboro dalam melakukan pembelian secara impulsif berdasarkan tipe pembelian impulsif dan menganalisis bagaimana tipe pembelian impulsif tersebut dalam pandangan Islam. Metode yang digunakan dalam penelitian ini adalah metode kuantitatif dengan menggunakan analisis uji pra survey berupa: Uji validitas, uji reliabilitas dan analisis frekuensi untuk menjelaskan hasil rata-rata jawaban dari para responden. Hasil dari penelitian ini adalah pengunjung Mall Malioboro Yogyakarta cenderung melakukan pembelian impulsif dengan tipe Pure Impulse dengan presentase sebesar $44 \%$ dan terdapat setidaknya tiga tipe pembelian impulsif yang tidak bertentangan dengan prinsip konsumsi Islami, yaitu Suggestion Impulse, Reminder Impulse, Planned Impulse.
\end{abstract}

Kata Kunci Pembelian Impulsif, Perspektif Islam

\section{A. Pendahuluan}

Manusia merupakan makhluk ciptaan Allah yang paling sempurna karena banyak dikaruniai kelebihan agar mampu bertahan hidup dengan cara pemenuhan kebutuhan masing-masing. Dalam pemenuhan kebutuhan tersebut, seorang manusia tidak mungkin dapat melakukannya seorang diri tanpa adanya peran dari orang lain. Jenis kebutuhan manusia pada dasarnya dibagi menjadi tiga macam, yaitu kebutuhan primer (dharuriyat), kebutuhan sekunder (hajiyyat), dan kebutuhan tersier (tahsiniyyat). Berdasarkan jenis kebutuhan tersebut, dapat dipastikan bahwa kebutuhan primer (dharuriyat) merupakan kebutuhan yang harus terlebih dahulu terpenuhi.

Yang menjadi perhatian adalah masyarakat, dalam memenuhi atau membeli barang-barang tersebut bukan karena hanya kebutuhan semata, namun telah bergeser pada mode atau trend yang terjadi di masyarakat. Misalnya salah satu kebutuhan manusia adalah pakaian, dalam membeli pakaian tersebut seringkali masyakarat melakukannya 
hanya karena trend yang terjadi saat itu sehingga berapapun biaya yang dikeluarkan tidak menjadi masalah hanya untuk memenuhi kepuasannya semata.

Kemudian, seringkali masyarakat dalam berbelanja untuk memenuhi kebutuhan hidupnya dilakukan secara spontan tanpa adanya perencanaan terlebih dahulu. Pembelian tanpa perencanaan inilah yang disebut dengan impulse buying. Menurut Beatty dan Ferrel dalam jurnal nya yang berjudul Impulse buying: Modeling its precursors, pembelian impulsif merupakan suatu pembelian yang segera dan tiba-tiba tanpa adanya niat sebelum belanja, untuk membeli kategori produk yang spesifik dan untuk memenuhi kebutuhan tertentu. ${ }^{1}$ Menurut Hausman, pembelian impulsive terjadi ketika konsumen mengalami suatu kejadian yang mendadak, sering kali muncul dorongan yang sangat kuat untuk membeli dengan segera. ${ }^{2}$

Point of Purchase Advertising Institute (POPAI) menyebutkan bahwa sekitar 75\% pembelian di supermarket dilakukan secara tidak terencana. ${ }^{3}$ Data ini didukung oleh hasil studi yang dilakukan Nichols et al, yang menyebutkan bahwa 50\% pembeli di pusat perbelanjaan melakukan pembelian secara impulsif. ${ }^{4}$

Saat ini gaya hidup lah yang mempengaruhi kebutuhan konsumen. Sebagian masyarakat telah terjebak dalam konsep kapitalis dimana dalam konsep ini tidak dibedakan antara need dan want. Keinginan dijadikan standar kepuasan bagaimana manusia mencukupi kebutuhan hidupnya. Keinginan dijadikan sebagai sebuah titik kepuasan sehingga konsep ini membawa manusia terjebak dalam perilaku konsumtif, hedonis. ${ }^{5}$ Semakin tinggi konsumen dengan motivasi hedonis dan berbelanja menjadi sebuah gaya hidup, maka besar kemungkinan terjadinya pembelian secara impulsif.

Ajaran Islam tidak melarang manusia untuk memenuhi keinginannya, semua yang ada di bumi ini diciptakan untuk kepentingan manusia:

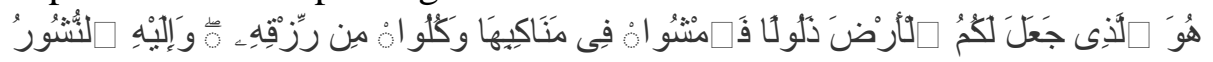

"Dialah Yang menjadikan bumi itu mudah bagi kamu, maka berjalanlah di segala penjurunya dan makanlah sebahagian dari rezeki-Nya. Dan hanya kepada-Nya-lah kamu (kembali setelah) dibangkitkan”. (QS. Al-Mulk [67]: 15)

Namun, manusia diperintahkan untuk mengkonsumsi barang/jasa yang halal dan baik saja secara wajar, tidak berlebihan. ${ }^{6}$ Pemenuhan keinginan tetap dibolehkan selama hal itu mampu menambah mashlahah atau tidak mendatangkan mudharat. Islam dalam hal konsumsi melarang bermewah-mewahan dan berlebih-lebihan, tetapi seorang muslim harus memperhatikan prinsip-prinsip konsumsi dalam islam. Dalam keadaan tertentu, seseorang terkadang tidak memperhatikan tingkat kebutuhan. Konsumen seringkali

\footnotetext{
1 Beatty and Ferrel, Impulse Buying: Modeling its Precursors, Journal of Retailing, Vol. 74 Issue 2, Summer 1998, pp. 169-191

2 A. Hausman, "A Muti-method Investigation of Consumer Motivation in Impulse Buying Behavior". Journal of Consumer Marketing, Vol. 17 No.5, 2000, pp. 403-417

${ }^{3}$ Astuti, R D. Fillipa,"Perbedaan Pembelian Secara Impulsif Berdasarkan Tingkat Kecenderungan, Kategori Produk, dan Pertimbangan Pembelian", Jurnal Ichsan Gorontalo, Vol. 3, No.1, 2008, pp. 1441-1456

4 Coley, A and Burges, Gender Differences in Cognitive and Affective Impulse Buying, Journal of Fashion Marketing and Management, Vol.7 No.3, 2003, pp.282-295 hlm. 107

${ }^{5}$ Rozalinda, Ekonomi Islam Teori dan Aplikasinya pada Aktifitas Ekonomi, Jakarta: Rajawali Pers, 2016,

${ }^{6}$ Al-Qur'an [7]: 31-32 dan QS [5]: 88
} 
menempatkan kebutuhan hajjiyah sebagai dharuriyah, tahsiniyah sebagai hajjiyah bahkan tahsiniyah sebagai dharuriyah. ${ }^{7}$

Globalisasi ekonomi berimplikasi pada prilaku konsumsi masyarakat modern pada saat ini. Perhatikan table berikut :

\section{Rata-Rata Pengeluaran per Kapita Sebulan di Daerah Perkotaan dan Perdesaan Menurut Provinsi di pulau Jawa (rupiah), 2015-2017}

\begin{tabular}{|c|c|c|c|c|c|c|c|c|c|}
\hline \multirow[t]{2}{*}{ Provinsi } & \multicolumn{3}{|c|}{ Makanan } & \multicolumn{3}{|c|}{ Non Makanan } & \multicolumn{3}{|c|}{ Jumlah } \\
\hline & 2015 & 2016 & 2017 & 2015 & 2016 & 2017 & 2015 & 2016 & 2017 \\
\hline \multirow[t]{3}{*}{ DKI Jakarta } & & & & 1 & & 1 & 1 & 1 & 1 \\
\hline & 615 & 692 & 797 & 157 & 1184 & 199 & 773 & 876 & 997 \\
\hline & 486 & 207 & 828 & 945 & 441 & 618 & 431 & 648 & 446 \\
\hline \multirow[t]{3}{*}{ Jawa Barat } & & & & & & & & & 1 \\
\hline & 425 & 477 & 562 & 471 & 506 & 540 & 896 & 983 & 103 \\
\hline & 883 & 814 & 767 & 012 & 063 & 571 & 895 & 877 & 337 \\
\hline \multirow[t]{3}{*}{ Jawa Tengah } & & & & & & & & & \\
\hline & 330 & 371 & 421 & 365 & 385 & 405 & 695 & 756 & 827 \\
\hline & 646 & 605 & 515 & 211 & 115 & 709 & 856 & 720 & 223 \\
\hline \multirow{3}{*}{$\begin{array}{l}\text { DI } \\
\text { Yogyakarta }\end{array}$} & & & & & & & & & 1 \\
\hline & 365 & 434 & 490 & 563 & 636 & 649 & 928 & 1070 & 140 \\
\hline & 012 & 004 & 249 & 591 & 958 & 918 & 602 & 962 & 166 \\
\hline \multirow[t]{3}{*}{ Jawa Timur } & & & & & & & & & \\
\hline & 380 & 427 & 476 & 449 & 443 & 461 & 830 & 870 & 938 \\
\hline & 993 & 191 & 861 & 479 & 221 & 940 & 472 & 412 & 801 \\
\hline \multirow[t]{3}{*}{ Banten } & & & & & & & 1 & 1 & 1 \\
\hline & 483 & 532 & 623 & 548 & 602 & 628 & 032 & 135 & 251 \\
\hline & 956 & 389 & 084 & 390 & 867 & 887 & 346 & 256 & 972 \\
\hline
\end{tabular}

Sumber Data : www.bps.go.id

Tingkat pengeluaran perkapita masyarakat provinsi DIY selama 3 tahun terakhir cukup tinggi. Provinsi DIY berada pada urutan ketiga, hanya kalah dari provinsi DKI Jakarta dan provinsi Banten dalam hal konsumsinya. Hal ini merupakan indicator bahwa masyarakat provinsi DIY memiliki kecenderungan perilaku yang konsumtif, sehingga kecenderungan untuk melakukan pembelian impulsive cukup tinggi.

Fokus kajian penulis dalam penelitian ini adalah untuk mengukur seberapa besar kecenderungan masyarakat provinsi DIY sebagai pengunjung Mall Malioboro dalam melakukan pembelian secara impulsif berdasarkan tipe pembelian impulsif dan menganalisis bagaimana tipe pembelian impulsif tersebut dalam pandangan Islam.

\section{B. Metode Penelitian}

Metode yang digunakan dalam penelitian ini adalah metode kuantitatif. Sampel dalam penelitian ini adalah sebanyak mungkin pengunjung mall malioboro Yogyakarta yang dianggap cukup memadai sebagai representative populasi. ${ }^{8}$ Sehingga peneliti mengambil sampel sejumlah 100 responden menggunakan teknik non probability sampling dengan cara random sampling berdasarkan jenjang usia produktif. Analisis data

\footnotetext{
7 Cucu Komala, Perilaku Konsumsi Impulsive Buying Perspektif Imam Ghazali, Jurnal Perspektif, Vol.2 No.2 Desember 2018, pp. 248-266

8 Suharsimi Arikunto, Prosedur Penelitian Suatu Pendekatan Praktek, Jakarta: Rineka Cipta, 2002, hlm. 25
} 
dalam penelitian ini menggunakan uji prasurvey, berupa : Uji validitas, uji reliabilitas dan analisis frekuensi untuk menjelaskan hasil rata-rata jawaban dari para responden.

Pengukuran data menggunakan angket tertutup dimana setiap pertanyaan diberikan pilihan dengan 4 alternatif jawaban (skala likert) dan setiap jawaban angket meliterasikan tipe pembelian impulsif sehingga dapat diketahui kecenderungan jawaban dari masing-masing responden, dan data diolah menggunakan alat analisis SPSS versi 24.

\section{Kajian Teori}

\section{Pembelian Impulsif}

\section{a. Pengertian Pembelian Impulsif}

Pembelian impulsive merupakan salah satu pembelian yang keputusannya diambil didalam toko. Ketika konsumen memutuskan untuk membeli sesuatu didalam toko (Spontaneous Shopping), satu dari dua proses yang berbeda akan terjadi, yaitu unplanned buying ataupun impulsive buying. Unplanned buying adalah ketika konsumen tidak kenal atau tidak terbiasa dengan layout toko atau mungkin konsumen tersebut sedang terburu-buru oleh waktu. Pembelian impulsive adalah ketika konsumen terdapatdorongan keinginan tiba-tiba yang tidak dapat ia hindari. ${ }^{9}$ Pengertian lebih lanjut mengenai pembelian impulsif oleh para ahli adalah pembelian impulsif diartikan sebagai pembelian ketika konsumen merasakan dorongan keinginan secara tiba-tiba,terkadang sangat kuat dan keras untuk membeli sesuatu secara cepat. ${ }^{10}$

Dengan pengertian-pengertian diatas,dapat disimpulkan sebagai pembelian yang tidak direncanakan, yang dikarakteristikan oleh pengambilan keputusan yang cenderung cepat,kompleksitas hedonis dan lebih banyak pengaruh emosionalnya, dan tidak disertakan dari pembelian yang mengingatkan kita pada suatu benda tertentu untuk memenuhi rencana tertentu, seperti membeli hadiah untuk orang lain. ${ }^{11}$

Tendensi pembelian impulsif lebih mengutamakan pada apa yang mendorong konsumen dalam melakukan pembelian impulsif. Pembelian impulsif adalah tendensi konsumen untuk membeli secara spontan, unreflectively, secara cepat, dan secara kinestetik. ${ }^{12}$

\section{b. Karakteristik Pembelian Impulsif}

Engel, Blackwell, Miniard mengemukakan lima karakteristik penting yang membedakan tingkah laku konsumen yang impulsive dan tidak impulsive. ${ }^{13}$ Karakteristik tersebut adalah:

1) Konsumen merasakan adanya suatu dorongan yang tiba-tiba dan spontan untuk melakukan tindakan yang berbeda dengan tingkah laku sebelumnya.

9 Solomon, M.R, “Consumer Behavior: buying, having, and being" (8 $8^{\text {th }}$ ed). Dalam Tesis Tania, PerilakuPembelian Impulsf Produk Pakaian Masyarakat Urban di Kota Jakarta dan Bandung, Fakultas Ekonomi Magister Manajemen, UI, 2010, hlm. 32

10 Rook, D.W, “The Buying Impulse”, Journal of Consumer Research, 14 Sept 1987, pp. 189-199

11 Mai, N, et.al, "An Exploratory Investigation into Impulse Buying Behaviorin a Transtional Economy:A Study of Urban Consumers in Vietnam", Journal of International Marketing, Vol. 11, 2003, pp. 1631

12 Rook dan Fisher, "Normative Influences on Impulsive Buying Behavior, Journal of Consumer Research, 1995, pp. 305-313

13 Engel, J.F, Blackwell, R.D, and Miniard, P.W, “Consumer Behavior", (10th ed), Mason: Thomson South-Western, 2006, Dalam Tesis Tania, hlm. 34 
2) Dorongan tiba-tiba untuk melakukan suatu pembelian menempatkan konsumen dalam keadaan tidak seimbang secara psikologis, dimana konsumen tersebut merasa kehilangan kendali untuk sementara waktu.

3) Konsumen akan mengalami konflik psikologis dan berusaha untuk mengimbangi antara pemuas kebutuhan langsung dan konsekuensi jangka panjang dari pembelian

4) Konsumen akan mengurangi evaluasi kognitif dari produk

5) Konsumen seringkali membeli secara impulsive tanpa memperhatikan konsekuensi yang akan datang.

Elemen-elemen tersebut dapat dikelompokan menjadi dua elemen pokok, yaitu kurangnya perencanaan dan pemikiran yang matang dalam pembelian produk yang dilakukan secara impulsive dan adanya respon emosi yang muncul sebelum, bersamaan, ataupun sesudah pembelian yang tidak direncanakan.

\section{c. Tipe Pembelian Impulsif}

Loundon dan Bitta mengemukakan empat tipe pembelian impulsif ${ }^{14}$, yakni:

1) Pure Impulse

Merupakan tipe pembelian impulsif dimana konsumen membeli tanpa pertimbangan, atau dengan kata lain pembeli tidak membeli dengan pola yang biasa ia lakukan.

\section{2) Suggestion Impulse}

Merupakan tipe pembelian impulsive dimana konsumen tidak mengetahui mengenai suatu produk, tetapi ketika melihat produk tersebut untuk pertama kali, ia tetap membelinya karena mungkin memerlukannya.

\section{3) Reminder Impulse}

Merupakan tipe pembelian impulsif dimana konsumen melihat suatu produk dan mengingat bahwa ia membutuhkan produk tersebut dikarenakan persediaan yang berkurang.

4) Planned Impulse

Merupakan tipe pembelian impulsif dimana konsumen memasuki toko dengan harapan dan intensi untuk melakukan transaksi pembelian berdasarkan harga khusus, kupon, dan kesukaan.

Terdapat empat jenis pembelanja impulsive ${ }^{15}$

1) Tipe kompensatif. Orang yang termasuk dalam tipe ini biasanya berbelanja karena ingin meningkatkan harga diri. Bagi mereka berbelanja merupakan sarana untuk melarikan diri dari berbagai masalah yang dihadapi, seperti masalah pekerjaan, rumah tangga, atau keluarga.

2) Tipe akseleratif. Orang yang termasuk dalam tipe ini sering kali tergoda berbelanja pada saat banyak penawaran sale di pusat-pusat perbelanjaan. Mereka akan membeli barangbarang tersebut, meskipun tidak membutuhkannya saat membeli. Barang-barang yang dibeli murah tersebut dapat digunakan untuk mengantisipasi kebutuhan di masa depan.

14 Loudon, D.L, \& Bitta, A.J, Consumer Behavior: Concept and Application (4th ed) (book), Singapore: McGraw-Hill, 2003, hlm. 35

${ }^{15}$ Cucu Komala, Op.,CIt, hlm. 252-253 
3) Tipe terobosan. Orang yang termasuk dalam tipe ini akan membeli barang-barang mahal tanpa ada perencanaan yang matang. Ketika berjalan-jalan di pusat perbelanjaan dan melihat ada pameran mobil atau rumah, mereka akan pulang dengan menandatangi kontrak pembelian rumah atau mobil baru tersebut. Bagi mereka membeli barang-barang mahal tersebut menjadi lambang dimulainya babak baru dalam kehidupannya, meskipun sebenarnya hasrat untuk membelinya sudah lama ada.

4) Tipe pembeli buta. Orang yang termasuk dalam tipe ini akan membeli barang tanpa ada pertimbangan sama sekali. Sulit sekali memahami apa yang melatarbelakangi mereka berbelanja seperti itu.

\section{d. Faktor Yang Mempengaruhi Pembelian Impulsif}

Terdapat beberapa faktor yang mempengaruhi seseorang untuk melakukan pembelian secara impulsif, yaitu karakteristik produk, karakteristik pemasaran dan karakteristik konsumen yang muncul sehubungan dengan proses pembelian ${ }^{16}$

1) Karakteristik produk, yaitu memiliki harga yang rendah, sedikit kebutuhan terhadap produk tersebut, siklus kehidupan produknya pendek, ukurannya kecil atau ringan dan mudah disimpan.

2) Karakteristik pemasaran. Dalam marketing hal yang mempengaruhi pembelian impulsif adalah : Distribusi massa dan self-service outlet. Ketersediaan informasi secara langsung berhubungan dengan produk yang dipasarkan. Pemasangan iklan, barang yang dipamerkan, websites, penjaga toko, paket-paket, adanya discount, dan sumber yang bebas informasi konsumen menjadi daya tarik tersendiri; posisi barang yang dipamerkan dan lokasi toko yang srategis dapat mempengaruhi pembelian impulsif. Kunjungan ke toko membutuhkan waktu, energi, dan uang, jarak kedekatan dari toko seringkali memberikan pengaruh terhadap konsumen dalam hal pembelian

3) Karakteristik konsumen yang mempengaruhi pembelian impulsif meliputi; kepribadian, demografis yang terdiri dari gender, usia, status perkawinan, pekerjaan dan Pendidikan dan yang terakhir adalah karakteristik sosio-ekonomi yang mempengaruhi tingkat pembelian impulsif. ${ }^{17}$

\section{Konsumsi Dalam Islam}

Islam sangat menghargai kemaslahatan manusia dengan membuat batasanbatasan atau rambu-rambu dalam berkonsumsi. Israf (tidak berlebihan) dan tidak mengonsumsi makanan yang haram termasuk salah satu rambu yang diatur dalam Islam. Hal ini tercantum dalam Al-Qur'an pada surat Al-Isra ayat 26-27 dan An-Nahl ayat 114.

Yusuf Qardhawi menyebutkan beberapa variable moral dalam berkonsumsi, diantaranya konsumsi atas alasan dan pada barang-barang yang baik (halal), berhemat, tidak bermewah-mewahan, menjauhi hutang, dan menjauhi kebakhilan dan kekikiran. ${ }^{18}$

16 Loudon D. L. \& Bitta, A. J. Consumer Behavior Concept and Application( 4th edition) [Book]. Singapore : McGraw-Hill. Hal. 35, 2003, dalam Cucu K, PERILAKU KONSUMSI IMPULSIVE BUYING PERSPEKTIF IMAM AL-GHAZALI, Jurnal Perspektif Vol. 2 No. 2 Desember 2018 Page 248-266.

17 Ibid.,

18 Yusuf Qardhawi, Peran Nilai dan Moral Dalam Perekonomian Islam, Jakarta: Rabbani Press, 1995 
Dalam konsep Islam, kebutuhanlah yang membentuk pola konsumsi seorang muslim. Pola konsumsi yang didasarkan pada kebutuhan akan menghindari pola konsumsi yang tidak perlu. Islam mengajarkan kesederhanaan, control diri, dan kehati-hatian dalam membelanjakan kekayaan. ${ }^{19}$

Terdapat prinsip-prinsip yang harus dipatuhi dan diperhatikan dalam berkonsumsi bagi seorang muslim, yakni: ${ }^{20}$

a. Konsumsi Barang Halal

Seorang muslim diperintahkan untuk mengonsumsi barang/makanan yang halal (sah menurut hokum dan diizinkan) dan tidak mengambil yang haram. Al-Qur'an menyatakan :

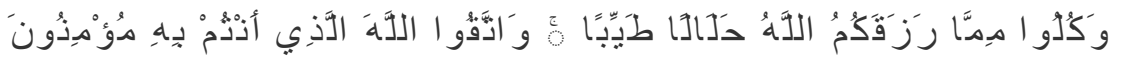

Artinya: Dan makanlah makanan yang halal lagi baik dari apa yang Allah telah rezekikan kepadamu, dan bertakwalah kepada Allah yang kamu beriman kepadaNya. (QS. Al-Ma'idah: 88)

Prinsip halal-haram juga berlaku bagi hal lain selain makanan. Quraish Shihab menjelaskan dalam tafsir al-Misbah, bahwa komoditi yang haram itu ada dua macam, yaitu haram karena zatnya seperti babi, bangkai, dan darah. Dan haram karena sesuatu bukan karena zatnya seperti makanan yang tidak diijinkan oleh pemiliknya. Komoditi yang halal adalah yang tidak termasuk dari dua macam tersebut. $^{21}$

b. Konsumsi Barang Suci dan Bersih

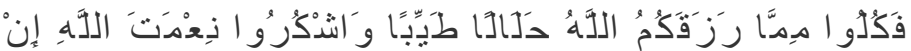

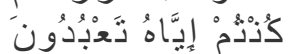

Artinya: Maka makanlah yang halal lagi baik dari rezeki yang telah diberikan Allah kepadamu; dan syukurilah nikmat Allah, jika kamu hanya kepada-Nya saja menyembah. (QS. An-Nahl: 114)

Kata yang digunakan Al-Qur'an adalahh "Thayyib" yang bermakna menyenangkan, manis, diizinkan, menyehatkan, suci,dan kondusif untuk kesehatan. Kata "Khabaits" adalah lawan Thayyib yang berarti barang-barang yang tidak suci. Seorang musim hanya mengonsumsi makanan/barang yang thayyib dan menjauhkan diri dari khabaita. ${ }^{22}$

c. Tidak Berlebihan (Israf)

19 Muhammad Sharif Chaudry, Sistem Ekonomi Islam : Prinsip Dasar, Terj. Suherman Rosyidi, Jakarta: Prenada Media Group, 2016, hlm. 137

${ }^{20}$ Ibid.,

${ }^{21}$ M. Muflih, Perilaku Konsumen Dalam Perspektif Ekonomi Islam, Jakarta: PT Raja Grafindo Persada, 2006, hlm. 86

${ }^{22}$ M. Sharif Chaudhry., Op.Cit, hlm. 139 
Islam memberikan sikap yang tegas untuk budaya konsumerisme, yaitu pelarangan terhadap sesuatu yang berlebih-lebihan, dan tidak mendatangkan manfaat. Disebutkan dalam Al-Qur'an:

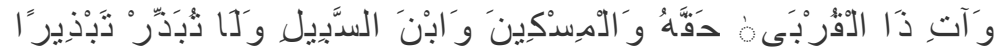

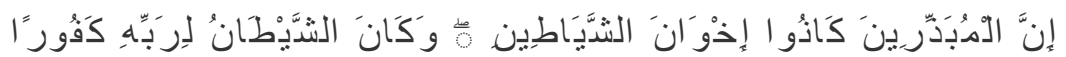

Artinya: Dan berikanlah kepada keluarga-keluarga yang dekat akan haknya, kepada orang miskin dan orang yang dalam perjalanan dan janganlah kamu menghambur-hamburkan (hartamu) secara boros. (26) Sesungguhnya pemborospemboros itu adalah saudara-saudara syaitan dan syaitan itu adalah sangat ingkar kepada Tuhannya. (QS. Al-Isra': 26-27)

Berlebih-lebihan termasuk sesuatu yang sangat ditentang oleh Islam. Menurut Muhammad Hasan al-Hamshi, pemborosan itu sangat terkait kadar ketaatan kita kepada Allah. ${ }^{23}$ Semakin boros seseorang, maka semakin lemah tingkat ketaatannya kepada Allah, demikian pula sebaliknya.

Imam Syafi'I memberikan pernyataan bahwa tabdzir adalah membelanjakan harta untuk sesuatu yang tidak dibenarkan. Jumhur ulama berpendapat bahwa didalam hal kebaikan tidak ada istilah mubadzir. Akan tetapi, barang siapa yang membelanjakan hartanya demi nafsu belaka dan melebihi kebutuhannya sampai hartanya habis, maka ia termasuk kategori pemboros. ${ }^{24}$

Dikatakan berlebih-lebihan jika dalam pemenuhan kebutuhan seharihari diluar batas kewajaran. Yaitu berlebih-lebihan dalam hal makanan, berpakaian, membangun rumah, dan pemenuhan hiburan. Jadi, jika seseorang membelanjakan uangnya untuk kebutuhan hidupnya secara layak, maka ia tidak termasuk orang-orang yang boros.

Umar Chapra mengatakan bahwa gaya hidup yang berlebihan dan pemborosan akan mengurangi perasaan senasib dan melemahkan ikatan persaudaraan suatu masyarakat muslim. ${ }^{25}$

Islam tidak melarang umatnya untuk bersenang-senang dan menikmati kehidupan dunia. Namun dalam tetap berada dalam koridor keseimbangan. Dalam Al-Qu'ran disebutkan:

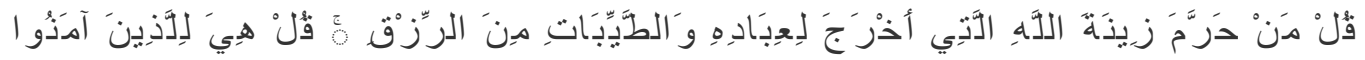

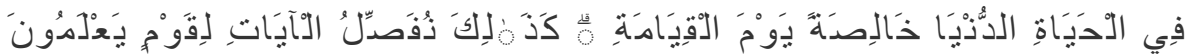

Katakanlah: "Siapakah yang mengharamkan perhiasan dari Allah yang telah dikeluarkan-Nya untuk hamba-hamba-Nya dan (siapa pulakah yang

${ }^{23}$ Muhammad Hasan al-Hamshi, Mufradat al-Syamilah al-Ishdar 2,8: Fiqh al-Am wa al-Fatawa: Fatawa al-Azhar: Min Ahkami Jam'I al-mal wa iddikharihi, Vol.6, hlm.157

${ }^{24}$ Lihat Maktabah al-Syamilah al-Ishdar 2,8 al-Tafasir: Al-Jami li Ahkan Al-Qur'anli al-Qurtubi, Vol.1, 3262

${ }^{25}$ M. Umer Chapra, Islam dan Tantangan Ekonomi, Terj. Ikhwan Abidin Basri, Jakarta: GIP \& Tazkia Institute, 2000, hlm. 210 
mengharamkan) rezeki yang baik?" Katakanlah: "Semuanya itu (disediakan) bagi orang-orang yang beriman dalam kehidupan dunia, khusus (untuk mereka saja) di hari kiamat". Demikianlah Kami menjelaskan ayat-ayat itu bagi orang-orang yang mengetahui. (QS. Al-A'raf: 32)

Islam mengajarkan sikap pertengahan. Tidak kikir dan tidak boros. Islam mengajarkan kesederhanaan dalam berkonsumsi tetapi juga tidak melarang umatnya untuk menikmati nikmat yang telah diberikan Allah SWT.

d. Berdasarkan Kebutuhan (Need), Bukan Keinginan (Want)

Dalam perspektif Islam, kebutuhan ditentukan oleh mashlahah. Pembahasan konsep kebutuhan dalam Islam tidak dapat dipisahkan dari kajian tentang perilaku konsumen dalam kerangka maqashid al-syariah. ${ }^{26}$

Menurut al-Ghazali, kebutuhan adalah keinginan manusia untuk mendapatkan sesuatu yang diperlukannya dalam rangka mempertahankan kelangsungan hidupnya dan menjalankan fungsinya. Konsumsi dilakukan dalam rangka mendekatkan diri kepada Allah SWT. ${ }^{27}$

Berbeda dengan ekonomi konvensional, yang tidak memisahkan antara keinginan dan kebutuhan, sehingga memicu terjebaknya budaya konsumerisme. Banyak kalangan yang memprioritaskan keinginan mereka karena tuntutan gaya hidup daripada mempertimbangkan kemaslahatan yang ada.

Memenuhi kebutuhan dan bukan kepuasan/keinginan merupakan tujuan dari aktifitas ekonomi Islam, dan usaha untuk pencapaian tujuan tersebut merupakan salah satu kewajiban dalam agama.

\section{Pembahasan}

\section{Kecenderungan Pembelian Impulsif}

Dari hasil penyebaran kuisioner dan data diolah menggunakan SPSS versi 24 maka diperoleh hasil sebagai berikut:

\begin{tabular}{|c|c|c|c|c|c|}
\hline & & \multicolumn{2}{|c|}{ Quisioner } & \multirow[b]{2}{*}{$\begin{array}{c}\text { Valid } \\
\text { Percent }\end{array}$} & \multirow[b]{2}{*}{$\begin{array}{c}\text { Cumulative } \\
\text { Percent }\end{array}$} \\
\hline & & Frequency & Percent & & \\
\hline \multirow[t]{5}{*}{ Valid } & Pure impulse & 44 & 44.0 & 44.0 & 44.0 \\
\hline & $\begin{array}{l}\text { Suggestion } \\
\text { Impulse }\end{array}$ & 24 & 24.0 & 24.0 & 68.0 \\
\hline & Reminder Impulse & 17 & 17.0 & 17.0 & 85.0 \\
\hline & Planned impulse & 15 & 15.0 & 15.0 & 100.0 \\
\hline & Total & 100 & 100.0 & 100.0 & \\
\hline
\end{tabular}

Sumber: Data diolah peneliti (2019)

Berdasarkan hasil pengolahan data diatas, didapatkan hasil persentasi jawaban dari para responden yang mengarah kepada hasil "pure impulse" sebesar $44 \%$. Hal ini berarti bahwa sebagian pengunjung mall malioboro cenderung melakukan pembelian

${ }^{26}$ Muhammad, Ekonomi Mikro dalam Perspektif Islam, Yogyakarta: BPFE, 2004, hlm. 152

27 Mustafa Edwin Nasution, dkk., Pengenalan Eksklusif Ekonomi Islam, Jakarta: Kencana Prenadamedia Group, 2006, hlm. 69 
tanpa pertimbangan dan membeli barang dengan pola yang berbeda dari yang biasa ia lakukan.

Kemudian didapatkan persentasi hasil sebesar $24 \%$, dimana jawaban responden mengarah kepada pembelian "suggestion impulse" yang artinya terkadang responden dalam melakukan pembelian yang tidak direncanakan, responden tidak mengetahui informasi mengenai produk tersebut sebelumnya namun produk tersebut tetap dibeli karena dianggap akan dibutuhkan dimasa yang akan datang.

Dan sebanyak $17 \%$ responden memberikan tanggapan yang mengarah kepada pembelian "reminder impulse", yang berarti bahwa pengunjung mall malioboro melakukan pembelian secara spontan yang disebabkan ia melihat suatu barang kemudian ia membeli barang tersebut, karena ia ingat bahwa ia membutuhkan barang tersebut atas dasar pertimbangan kebutuhan persediaan yang telah habis.

$15 \%$ hasil jawaban responden mengarah kepada planned impulse yang mana responden telah merencanakan untuk membeli suatu barang dengan harga khusus / diskon walaupun ia tidak merencanakan untuk melakukan pembelian terhadap produk itu sebelumnya.

Sehingga dapat disimpulkan bahwa berdasarkan keempat tipe pembelian impulsif dan berbagai tanggapan responden mengenai hal tersebut, mayoritas pengunjung mall malioboro cenderung melakukan pembelian impulsive dengan tipe pure impulsif yaitu sebesar 44\%. Hal ini berbading lurus dengan data yang diperoleh dari BPS yang menunjukkan bahwa provinsi DIY menduduki urutan ke tiga se-provinsi di pulau jawa dimana masyarakat provinsi DIY memiliki kecenderungan perilaku yang konsumtif. ${ }^{28}$

Menurut berbagai penelitian yang dilakukan baik dalam bentuk jurnal, skripsi, tesis maupun artikel, perilaku konsumtif cenderung dilakukan oleh kalangan anak muda. Mayoritas sampel dalam penelitian ini adalah kalangan mahasiswa. Provinsi DIY merupakan salah satu destinasi yang paling diminati oleh kalangan akademisi dan mahasiswa sebab di kota ini terdapat banyak kampus ternama dan destinasi wisata yang cukup terkenal sehingga banyak pendatang dari berbagai provinsi dan kota yang menetap di kota tersebut terutama dari kalangan pengusaha, mahasiswa dan pelajar. ${ }^{29}$ Dengan adanya kemajuan teknologi dari berbagai aspek membuat masyarakat mudah untuk melakukan pembayaran dalam berbagai pembelian, seperti penggunaan kartu debet atau kartu kredit sehingga kecenderungan untuk melakukan perilaku konsumtif cukup tinggi. ${ }^{30}$

\section{Pembelian Impulsif Perspektif Islam}

Berdasarkan tipenya pembelian impulsif dibedakan menjadi empat, yakni: Pure Impulse,Suggestion Impulse, Reminder Impulse, dan Planned Impulse.

28 Lihat BPS, Rata-Rata Pengeluaran per Kapita Sebulan di Daerah Perkotaan dan Perdesaan Menurut Provinsi dan Kelompok Barang (rupiah), 2011-2017

29 https://id.wikipedia.org/wiki/Daerah_Istimewa_Yogyakarta, diakses pada tanggal 12 Mei 2019

${ }^{30}$ Laila Ramadani, Pengaruh Pengounaan Kartu Debit dan Uang Elektronik (E-M o n e y ) Terhadap Pengeluaran KonsumsiMahasiswa, JESP-Vol. 8, No 1 Maret 2016 ISSN (P) 2086-1575 E-ISSN 2502-7115 
a. Pure Impulse, merupakan tipe pembelian impulsif dimana konsumen membeli tanpa pertimbangan, atau dengan kata lain pembeli tidak membeli dengan pola yang biasa ia lakukan. Artinya konsumen hanya membeli barang yang ia sukai tanpa mempertimbangkan apakah barang tersebut baik untuknya ,berguna baginya atau memang ia butuhkan. Konsumsi yang seperti ini tentunya sangat dilarang dalam Islam, karena salah satu prinsip konsumsi Islam adalah tidak berlebihan dan membeli barang berdasarkan kebutuhan bukan keinginan. Jadi Pure Impulse tidak boleh dilakukan seorang konsumen muslim demi menghindari hal-hal yang mudharat bagi dirinya.

b. Suggestion Impulse, merupakan tipe pembelian impulsive dimana konsumen tidak mengetahui mengenai suatu produk, tetapi ketika melihat produk tersebut untuk pertama kali, ia tetap membelinya karena mungkin memerlukannya. Pembelian impulsif seperti ini tidak dilarang dalam Islam, selama ia memang memerlukan barang tersebut. Selama barang tersebut tidak mengandung unsur yang diharamkan dan pembeliannya tidak berlebihan maka tipe pembelian impulsif seperti ini tidak dilarang.

c. Reminder impulse, merupakan tipe pembelian impulsif dimana konsumen melihat suatu produk dan mengingat bahwa ia membutuhkan produk tersebut dikarenakan persediaan yang berkurang. Tipe pembelian impulsive seperti ini tidak dilarang dalam Islam. Sebab, ia memang membutuhkan produk tersebut bukan hanya karena untuk memenuhi keinginannya semata. Pembelian secara spontan seperti ini cukup sering dilakukan oleh masyarakat, namun tetap harus dalam batas kewajaran dalam pembeliannya sehingga terhindar dari perilaku konsumtif.

d. Planned Impulse, merupakan tipe pembelian impulsif dimana konsumen memasuki toko dengan harapan dan intensi untuk melakukan transaksi pembelian berdasarkan harga khusus, kupon, dan kesukaan. Dalam konsumsi Islami, pembelian seperti ini tidak diharamkan selama ia memang membutuhkan barang tersebut dan cenderung lebih hemat (tidak boros). Akan tetapi pembelian impulsive dengan tipe seperti ini cenderung berbahaya karena umumnya jenis konsumen ini adalah tipe akseleratif dimana Orang yang termasuk dalam tipe ini sering kali tergoda berbelanja pada saat banyak penawaran sale di pusat-pusat perbelanjaan. Tipe seperti ini cenderung terjebak dalam promosi yang dilakukan oleh penjual. Mereka akan membeli barangbarang tersebut, meskipun tidak membutuhkannya. Yang pada akhirnya akan berdampak pada budaya konsumerisme dan hedonism.

\section{E. Kesimpulan}

Hasil dari penelitian tentang kecenderungan pembelian impulsive (tidak direncanakan) menunjukan bahwa, sebesar $44 \%$ responden yang dalam hal ini adalah pengunjung Mall Malioboro Yogyakarta cenderung melakukan pembelian impulsif dengan tipe Pure Impulse, dimana dalam tipe ini pengunjung melakukan pembelian tanpa pertimbangan sebelumnya. Pembelian impulsif dengan tipe ini bertentangan dengan Islam karena hanya berdasarkan selera, preferensi, kesukaan, tanpa mempertimbangkan apakah barang tersebut baik untuknya ,berguna baginya atau memang ia butuhkan.

Kemudian dari keempat tipe pembelian impulsif, terdapat setidaknya tiga tipe yang tidak bertentangan dengan prinsip konsumsi Islami, selama pembelian tersebut tetap 
berada dalam batas prinsip konsumsi Islam yaitu : konsumsi barang halal, konsumsi barang suci dan bersih, tidak berlebihan,dan konsumsi berdasarkan kebutuhan bukan keinginan. Pembelian impulsif yang tidak bertentangan dengan prinsip Islam tersebut adalah Suggestion Impulse, Reminder Impulse, Planned Impulse.

\section{REFERENSI}

A.Hausman, "A Muti-method Investigation of Consumer Motivation in Impulse Buying Behavior”. Journal of Consumer Marketing, Vol. 17 No.5, 2000, pp. 403-417.

Astuti, R D. Fillipa,"Perbedaan Pembelian Secara Impulsif Berdasarkan Tingkat Kecenderungan, Kategori Produk, dan Pertimbangan Pembelian", Jurnal Ichsan Gorontalo, Vol. 3, No.1, 2008, pp. 1441-1456.

Badan Pusat Statistik, Rata-Rata Pengeluaran per Kapita Sebulan di Daerah Perkotaan dan Perdesaan Menurut Provinsi dan Kelompok Barang (rupiah), 2011-2017

Beatty and Ferrel, Impulse Buying: Modeling its Precursors, Journal of Retailing, Vol. 74 Issue 2, Summer 1998, pp. 169-191.

Coley, A and Burges, Gender Differences in Cognitive and Affective Impulse Buying, Journal of Fashion Marketing and Management, Vol.7 No.3, 2003, pp.282-295.

Cucu Komala, Perilaku Konsumsi Impulsive Buying Perspektif Imam Ghazali, Jurnal Perspektif, Vol.2 No.2 Desember 2018, pp. 248-266.

Engel, J.F, Blackwell, R.D, and Miniard, P.W, “Consumer Behavior”, (10th ed), Mason: Thomson South-Western, 2006.

https://id.wikipedia.org/wiki/Daerah_Istimewa_Yogyakarta

Laila Ramadani, Pengaruh Penggunaan Kartu Debit dan Uang Elektronik (E-M o n e y) Terhadap Pengeluaran Konsumsi Mahasiswa, JESP-Vol. 8, No 1 Maret 2016 ISSN (P) 2086-1575 E-ISSN 2502-7115.

Loudon, D.L, \& Bitta, A.J, Consumer Behavior: Concept and Application ( $\left.4^{\text {th }} \mathrm{ed}\right)$ (book), Singapore: McGraw-Hill, 2003.

Mai, N, et.al, "An Exploratory Investigation into Impulse Buying Behaviorin a Transtional Economy: A Study of Urban Consumers in Vietnam", Journal of International Marketing, Vol. 11, 2003, pp. 16-31.

Maktabah al-Syamilah al-Ishdar 2,8 al-Tafasir: Al-Jami li Ahkan Al-Qur'anli al-Qurtubi, Vol.1, 3262.

M. Muflih, Perilaku Konsumen Dalam Perspektif Ekonomi Islam, Jakarta: PT Raja Grafindo Persada, 2006. 
M. Umer Chapra, Islam dan Tantangan Ekonomi, Terj. Ikhwan Abidin Basri, Jakarta: GIP \& Tazkia Institute, 2000.

Muhammad, Ekonomi Mikro dalam Perspektif Islam, Yogyakarta: BPFE, 2004.

Muhammad Hasan al-Hamshi, Mufradat al-Syamilah al-Ishdar 2,8: Fiqh al-Am wa alFatawa: Fatawa al-Azhar: Min Ahkami Jam'I al-mal wa iddikharihi, Vol.6.

Muhammad Sharif Chaudry, Sistem Ekonomi Islam : Prinsip Dasar, Terj. Suherman Rosyidi, Jakarta: Prenada Media Group, 2016

Mustafa Edwin Nasution, dkk., Pengenalan Eksklusif Ekonomi Islam, Jakarta: Kencana Prenadamedia Group, 2006.

Rook, D.W, “The Buying Impulse”, Journal of Consumer Research, 14 Sept 1987, pp. 189-199.

Rook dan Fisher, "Normative Influences on Impulsive Buying Behavior, Journal of Consumer Research, 1995, pp. 305-313.

Rozalinda, Ekonomi Islam Teori dan Aplikasinya pada Aktifitas Ekonomi, Jakarta: Rajawali Pers, 2016.

Suharsimi Arikunto, Prosedur Penelitian Suatu Pendekatan Praktek, Jakarta: Rineka Cipta, 2002.

Solomon, M.R, “Consumer Behavior: buying, having, and being” ( $\left.8^{\text {th }} \mathrm{ed}\right)$.

Tania, Perilaku Pembelian Impulsf Produk Pakaian Masyarakat Urban di Kota Jakarta dan Bandung, Fakultas Ekonomi Magister Manajemen, UI, 2010.

Yusuf Qardhawi, Peran Nilai dan Moral Dalam Perekonomian Islam, Jakarta: Rabbani Press, 1995. 